International Journal of Social Sciences and Humanities
Available online at http://sciencescholar.us/journal/index.php/ijssh
Vol. 3 No. 2, August 2019, pages: 156 164
e-ISSN: 2550-7001, p-ISSN: 2550-701X
https://doi.org/10.29332/ijssh.v3n2.307

\title{
Syntactical Analysis of Essays
}

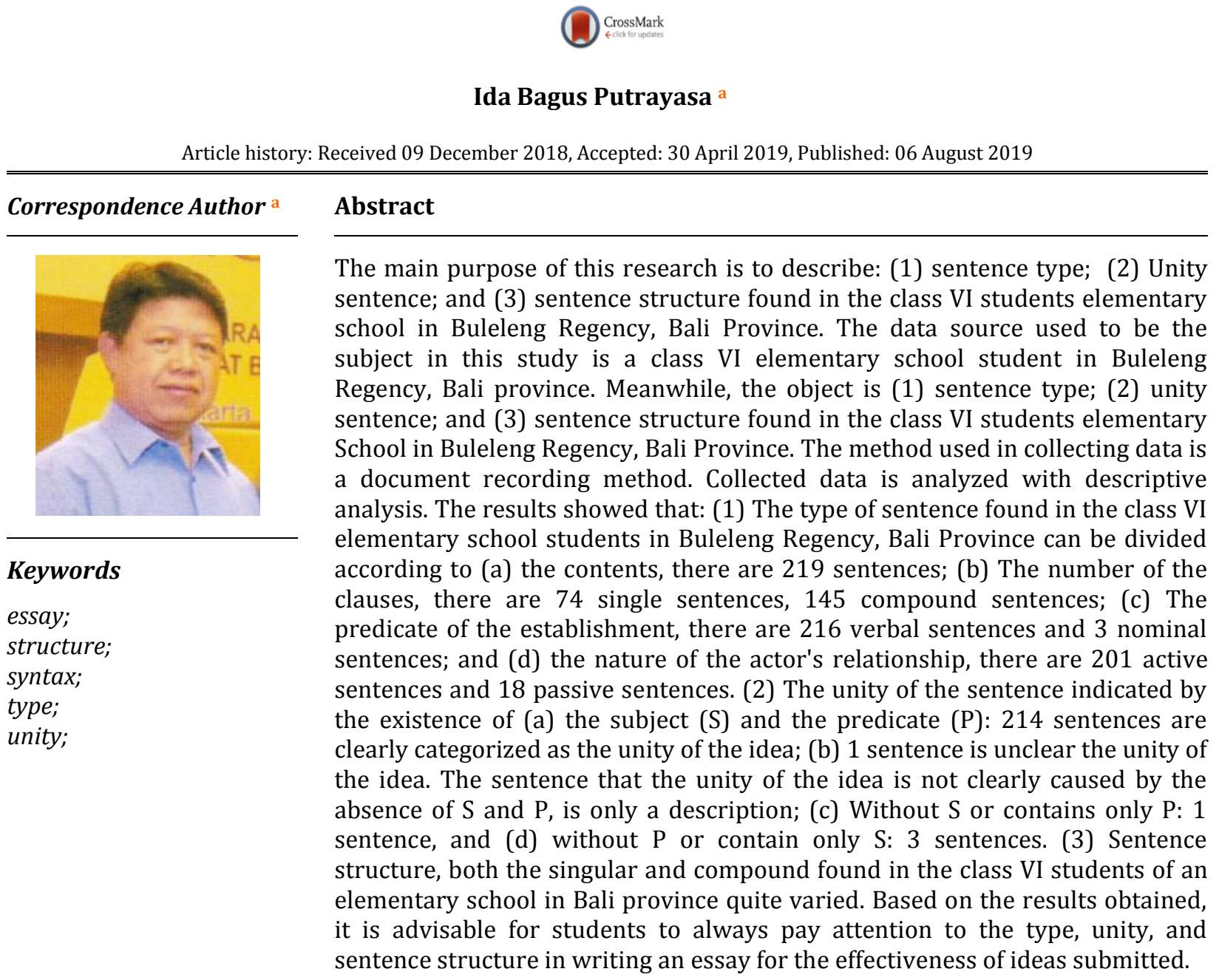

e-ISSN: 2550-7001, p-ISSN: 2550-701X ๑ Copyright 2019. The Author. SS Journals Published by Universidad Técnica de Manabí. This is an open-access article under the CC BY-SA 4.0 license (https://creativecommons.org/licenses/by-sa/4.0/) All rights reserved.

\section{Contents}

Abstract 156

1. Introduction. 157

a Universitas Pendidikan Ganesha, Singaraja, Indonesia 


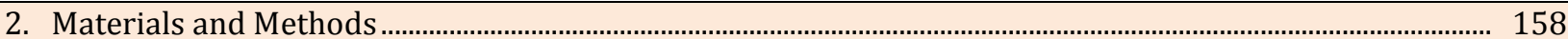

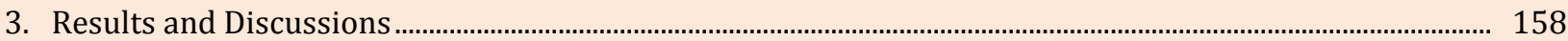

3.1 Types of Sentences in Class VI Elementary School Students in Buleleng Regency, Bali Province......... 158

3.2 Sentence Unity in Essays of Class VI Elementary School Students in Buleleng Regency, Bali

Province

3.3 Sentence Structure in Essays of Class VI Elementary School Students in Buleleng Regency,

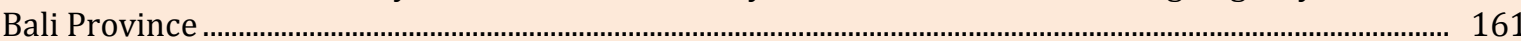

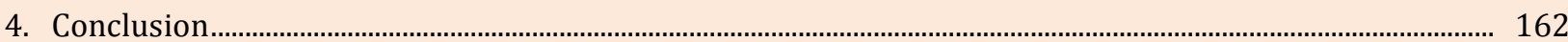

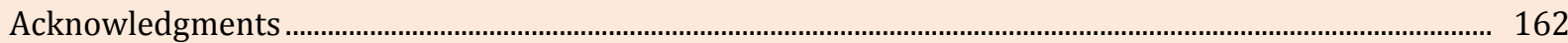

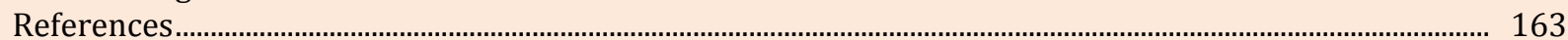

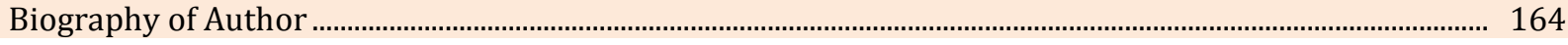

\section{Introduction}

The ultimate goal of Bahasa Indonesia learning is skilled students. One of those language skills is writing skills. In writing necessary devices of the language, such as sentences. In writing ideas, students often have difficulty composing sentences. The sentences are put together, not clear the type, the unity of the idea, and the structure of the sentence, so that the idea conveyed cannot be understood properly. Therefore, sentences are very important to be understood and mastered when presenting ideas, both orally and in writing. A sentence is a string of words that forms a complete understanding (Reyner, 2016; Collins \& Stabler, 2016; Robert-Burton, 1997; Putrayasa, 2014c).

However, the word string is often found without complete understanding, which is used in both oral and written communication. One of these communications is found in a student's essay. The essay is a combination of several interconnected sentences, which contain ideas. This essay is later used only as a means of reviewing the sentences that students use in their work. In composing, students use a word string to pour out the idea, but the word string exists that does not contain a complete understanding. This incomplete understanding is demonstrated without the presence of a subject or predicate. This is what makes the essay interesting to be examined from the aspect of the type of sentence, the unity of the sentence, and the structure of the sentence. These aspects can sharpen the syntactic study in a student essay. In his research on syntactic, in particular, the sentence, Putrayasa (2008), revealed that students are still having difficulty in specifying the function of words in the sentence structure, either as a subject, predicate, object, complement, or description in a sentence.

The studies that have been done do not discuss in detail matters relating to the type of sentence, unity of sentences, and sentence structure. Putrayasa (2008), was conducted in the city of Singaraja, which only examines the subject and predicate in a student arrangement with a qualitative and quantitative approach. In 2010, research on the syntactic study was done again, but it only examines the student's mastery of distinguishing objects and complementary elements.

A fairly comprehensive study relates to the analysis of syntactically, in particular, the elements of sentences but performed separately, also performed by Putrayasa (2014; Syarifaturrahman et al., 2017; Paridi \& Sudika, 2018). His research examines differences in object elements and descriptions. The results show that students ' ability is still low (average: 5.75) in determining the elements of the sentence. This is due to the low understanding of the students ' concept of the sentence, the concept of the elements of forming sentences, both in terms of type, unity, and structure. In addition to the lack of exercises, how to determine the elements of the sentence. With the lack of understanding and exercises, this will impact the low quality of the language used to convey ideas, both orally and in writing (Yani et al., 2018; Darlina, 2016).

Based on the background description above, the formulation of a study and theory of syntax, particularly those relating to sentence type, unity of sentences, and sentence structure, maybe urgent to do. This study has a strategic position as a basis for further research development and can practically be used as a reference for knowledge in conveying ideas orally or written. As the research and statements from previous experts and researchers, mastery of the syntax (especially sentences) can be understood at least from three aspects of the study, namely: sentence type, sentence unit, and the sentence structure. What is the problem in this research is: (1) How is the type of sentence found in the class VI students of elementary School in Buleleng Regency,

Putrayasa, I. B. (2019). Syntactical analysis of essays. International Journal of Social Sciences and Humanities, 3(2), 156-164. https://doi.org/10.29332/ijssh.v3n2.307 
Bali province? (2) How is the unity of sentences found in the class VI elementary school students in Buleleng Regency, Bali province? And (3) How is the structure of sentences in the class VI elementary school students in Buleleng Regency, Bali province?

\section{Materials and Methods}

The study uses qualitative descriptive design, which is the business of planning and determining all the possibilities and equipment needed in a qualitative study (Lincoln \& Guba, 1985; Alwasilah, 2002), which essentially describes qualitatively in the form of words and not mathematical figures or statistics (Lindlof, 1994).

The source of this research data is the essay of Class VI elementary school in Buleleng Regency, Bali province. In the determination of the sample used a random sampling area technique, namely random to SD representing the city area, out of town, and suburbs. From each region will be taken 1 SD. From each SD will be taken 10 students essay. Thus, there are a total of 3 elementary schools and 30 student essays as members of the sample as shown in the table below.

Table 1

School samples and student essays

\begin{tabular}{llll}
\hline No. & Regency & Number of Elementary Schools & Number of Student Essays \\
\hline \multirow{3}{*}{1} & \multirow{2}{*}{ Buleleng } & 1 & 10 \\
& & 1 & 10 \\
Total & 3 & 10 \\
\hline
\end{tabular}

The method used in collecting data is a document recording method. That is, the essay students who have gathered by the teacher are analyzed based on the study object.

Once collected data is conducted inductive analyses (Lincoln \& Guba, 1985). That is, the special things found during the study were conducted, grouped together, and then made abstraction (Bogdan \& Biklen, 1990). In addition, aggregated data is not used to prove or reject hypotheses created before the study begins, but it is used to facilitate data description.

\section{Results and Discussions}

\subsection{Types of Sentences in Class VI Elementary School Students in Buleleng Regency, Bali Province}

In this section, the results are presented in accordance with the problems studied, namely the type of sentence based on: (1) the contents, (2) the number of the clauses, (3) Predictor, and (4) the nature of the actors' relationships contained in the class VI students Elementary School in Buleleng Regency, Bali Province.

The data is studied from the class VI elementary school students in Buleleng Regency, Bali province. The total essays are 30, of which each essay consists of 3 paragraphs. The total number of sentences is 219 . The entire sentence is examined from the aspects of its content, the number of the clauses, the predictor, and the nature of the actor's relationship, as shown in the description below.

Based on the analysis of the data done, the type of sentences found in the class VI elementary school students as shown in table 2 below. 
Table 2

Types of Sentences in Class VI Students Elementary School in Buleleng Regency, Bali Province

\begin{tabular}{|c|c|c|c|c|c|c|}
\hline \multirow[b]{2}{*}{ No. } & \multicolumn{4}{|c|}{ Sentence Type } & \multirow[b]{2}{*}{ Frequency } & \multirow[b]{2}{*}{ Total } \\
\hline & Content & $\begin{array}{l}\text { Number of } \\
\text { Clauses }\end{array}$ & $\begin{array}{l}\text { Establishment } \\
\text { Predicate }\end{array}$ & $\begin{array}{l}\text { The nature of } \\
\text { actor-action } \\
\text { relationships }\end{array}$ & & \\
\hline 1 & $\begin{array}{l}\text { Declarative } \\
\text { Sentence }\end{array}$ & - & - & - & 219 & \\
\hline 2 & $\begin{array}{l}\text { Interogative } \\
\text { Sentence }\end{array}$ & - & - & - & 0 & 219 \\
\hline 3 & $\begin{array}{l}\text { Imperative } \\
\text { Sentence }\end{array}$ & - & - & - & 0 & \\
\hline 4 & & $\begin{array}{l}\text { Single } \\
\text { Sentence }\end{array}$ & - & - & 74 & 219 \\
\hline 5 & & $\begin{array}{l}\text { Compound } \\
\text { Sentence }\end{array}$ & - & - & 145 & \\
\hline 7 & & & Verbal Sentence & - & 216 & 219 \\
\hline 8 & & & $\begin{array}{l}\text { Nominal } \\
\text { Sentence }\end{array}$ & - & 3 & \\
\hline $\begin{array}{c}9 \\
10\end{array}$ & & & & $\begin{array}{l}\text { Active Sentence } \\
\text { Passive } \\
\text { Sentence }\end{array}$ & $\begin{array}{l}201 \\
18\end{array}$ & 219 \\
\hline
\end{tabular}

From the table above, the following things can be described. Based on the contents found only one type of sentence, namely: declarative sentences which number: 219 sentences. Based on the number of clauses found two types of sentences, namely: 1) single sentences totaling: 74 pieces, 2) compound sentences amounting to 145 pieces. Based on the predicate of the establishment, two types of sentences are found, namely: 1) verbal sentences: 216 and 2) nominal sentences: 3 pieces. Based on the nature of actor-action relationship found two types of sentences, namely: 1) active sentences: 201 pieces and 2) passive sentences: 18 pieces.

In the explanation above, the types of sentences found in essays of class VI elementary school students in Buleleng regency, Bali province are only declarative sentences totaling 219 pieces. This is natural because the description of the object or the personal experience of the student needs to be informed to the public so that they know the results of the thoughts made by the students. The only tool used to convey this information is declarative sentences. This is in accordance with Putrayasa (2012, 2017, 2018a); Huddleston \& Uren (1981); and Osborne et al., (2012), that declarative sentences are sentences used to convey news or information. This news sentence is the most widely used in everyday life, both in conveying information that is scientific and non-scientific.

The second prominent finding related to the explanation above is the use of compound sentences in essays of sixth-grade students of an elementary school in Buleleng regency, Bali province. In the essay of students, there are more compound sentences, namely 145 pieces. This happens because students in conveying their ideas are influenced by their spoken language, do not pay attention to the rules of writing sentences, which are marked by the use of uppercase letters and end with punctuation (Putrayasa, 2018a). From this, the sentences are long, consisting of several subjects and several predicates, as shown in the data excerpt below.

sampai di rumah saya menyapu halaman supaya bersih sesudah menyapu saya menyuci piring karena banyak gelas dan piring yang kotor saat saya menyuci piring dan gelas bapak saya ingin mengajak saya ke sungai untuk mandi kalau sudah menyuci piring (Kr.5/P3/SD1.Bll.).

The above paragraph is a paragraph that occurs from the string of words, which actually if examined consists of several subjects and several predicates as long as following the rules of writing sentences. Because of the

Putrayasa, I. B. (2019). Syntactical analysis of essays. International Journal of Social Sciences and Humanities, 3(2), 156-164. https://doi.org/10.29332/ijssh.v3n2.307 
inaccuracy in the use of sentence writing rules, the paragraph above is not clear in its unity of ideas. This is in line with the results of research conducted by Yu Tai (2015), which shows that the results of the writing (the use of syntax) of second language learners are less accurate or less clear on the unity of ideas, so the writing is difficult to understand. In order to be clear about the unity of the ideas, the rules for composing the sentence must be fulfilled. The characteristics of the sentence in terms of writing rules should be marked with a capital letter at the beginning of the sentence and ending with punctuation: point, question, or exclamation (Putrayasa, 2018a; Robert-Burton, 1997; Nordquist, 2018). By following the rules, the sentences that make up the paragraph become clear the unity of the idea and the paragraph becomes effective.

In addition, elementary school students tend to arrange complex sentences in paragraphs. This happens along with the development of cognition and language development. This condition is in line with the views of Winch et al., (2006), who says that between language growth and intellectual growth both are closely intertwined. Increasing language skills, increasing his thinking ability or intellectual. This view is also supported by Batterink \& Neville (2013), who said that the sentences processed and produced by adult children tend to be in the form of compound sentences or complex sentences.

The next finding is that almost all of the sentences used in essays by class VI elementary school students in Buleleng Regency, Bali province are verbal sentences (216 sentences). A verbal sentence is a sentence whose predicate is a verb. In the use of everyday language, more verbs are predicated. No exception with the sentence in the essay of sixth-grade elementary school students in Buleleng regency, Bali province. This shows that human activities in daily life are doing work. Therefore, the sentence used in communicating every day is a verbal sentence. This is in accordance with the opinion of Putrayasa (2018a), which says that the type of sentence that is most widely used in everyday communication is verbal sentences, which are characterized by predicates of verbs. This statement is also supported by the results of research conducted by Hatch (1983) and Putrayasa (2017) which reveal that in everyday life most people do is work. In language, this work is characterized by verbal or types of verbs.

The last finding is the use of sentences contained in essays of class VI elementary school students in Buleleng regency, Bali province mostly in the form of active sentences (201 sentences). In expressing ideas, students use more active sentences. This happens because in expressing something that is preferred is the subject who does the work. Therefore, the sentence that is produced is an active sentence. An active sentence is a sentence whose subject is doing work (Nordquist, 2018).

\subsection{Sentence Unity in Essays of Class VI Elementary School Students in Buleleng Regency, Bali Province}

Based on the data analysis carried out, it was found the unity of the sentences contained in the essays of class VI elementary school students as shown in Table 3 below.

Table 3

Unity of Sentences in Essays of Class VI Elementary School Students in Buleleng Regency, Bali Province

\begin{tabular}{llll}
\hline No. & Unity of Sentence & Frequency & Total \\
\hline 1 & The existence of a subject (S) and predicate (P) & 214 & 214 \\
2 & Without S and P & 1 & 1 \\
3 & Without S (contain only P) & 1 & 1 \\
4 & Without P (contain only S) Total & 3 & 3 \\
\multicolumn{2}{c}{ Tota } & 219 \\
\hline
\end{tabular}

The table above shows that almost all data (214 sentences) fulfill the unitary elements of the sentence, namely the elements of the subject and predicate. There are 1 sentence that does not fulfill the unitary element, which does not contain $\mathrm{S}$ and $\mathrm{P}, 1$ sentence without $\mathrm{S}$ or only contains $\mathrm{P}$, and 3 sentences without $\mathrm{P}$ or only contains $S$. Seen from the number of sentences that fulfill the unitary element, this indicates that students understand well how to express ideas so that the ideas conveyed can be well understood by the reader. Of course, the ideas conveyed by the sentence must contain a complete understanding. In order for the sentences to be delivered to contain a complete understanding that in them there must be a subject and predicate. This is consistent with the opinion of Robert-Burton (1997) and Nordquist (2018), which reveals that a sentence 
must contain a subject and predicate. With the existence of a subject and predicate in a sentence, the sentence is easy to understand because it already contains a complete understanding. This opinion is supported by the results of research conducted by Putrayasa (2018a, b) which reveals that easily understood sentences are sentences which contain elements of Subjects and Predicates. It is this element of the Subject and Predicate that provides complete understanding.

Meanwhile, word strings that do not contain elements of the subject and predicate, which only contain the element $\mathrm{S}$, and which only contain the element $\mathrm{P}$ can be quoted as shown in the example below. (Full data can be seen in the attachment).

1) does not contain $S$ and $P$ elements:

- di sana tempatnya indah. (Kr.5/P1/SD1.Bll.).

2) dose not contain $\mathrm{S}$ (contain only $\mathrm{P}$ ):

- bangun dengan perasaan marah. (Kr.6/P2/SD1.Bll.).

3) does not contain P (contain only S):

- saya bersama sepupu-sepupu saya. (Kr.7/P3/SD1.Bll).

The above examples are strings that do not contain the complete understanding because there are no $\mathrm{S}$ and $\mathrm{P}$ elements (in example 1), there is no element $S$ (in example 2), and there is no element $P$ (in example 3 ). The three-word strands in the examples above are not sentences, because they do not contain complete understanding. In order for the word strand to contain the complete meaning, it should have $\mathrm{S}$ and $\mathrm{P}$ elements. The $\mathrm{S}$ and $\mathrm{P}$ elements are the word strands classified as sentences. This is in accordance with the opinion (Reyner, 2016; Collins \& Stabler, 2016; and Clifton \& Frevier, 2010), which states that sentences are strands that contain complete understanding. This complete understanding is characterized by the presence of elements S and P.

\subsection{Sentence Structure in Essays of Class VI Elementary School Students in Buleleng Regency, Bali Province}

Based on the data analysis carried out, it was found the structure of the sentence in essays of class VI elementary school students in Buleleng regency, Bali province as shown in Table 4 below.

Table 4

Sentence Structure in Essays of Class VI Elementary School Students in Buleleng Regency, Bali Province

\begin{tabular}{|c|c|c|}
\hline \multirow[t]{2}{*}{ No. } & \multicolumn{2}{|c|}{ Sentence Structure } \\
\hline & Single & Plural \\
\hline 1 & $S-P$ & S-S-P \\
\hline 2 & $\mathrm{~S}-\mathrm{P}-\mathrm{O}$ & S-S-P-O \\
\hline 3 & $S-P-K$ & S-S-P-Pel \\
\hline 4 & $S-P-K-K$ & S-P-P \\
\hline 5 & S - P - Pel & S-P / S-P \\
\hline 6 & $S-P-O-K$ & S-S-P-O / P-O \\
\hline 7 & $\mathrm{P}-\mathrm{S}$ & S-P-O-K / S-P-O-K \\
\hline 8 & $\mathrm{P}-\mathrm{S}-\mathrm{K}$ & S-P-O / S-P / S-P-K / S-P \\
\hline 9 & $\mathrm{~K}-\mathrm{S}-\mathrm{P}$ & S-P-P-P-O-K \\
\hline 10 & $\mathrm{~K}-\mathrm{P}-\mathrm{S}$ & S-P-O / S-P / K-S-P-K / K-S-P / S-P \\
\hline 11 & $\mathrm{~K}-\mathrm{K}-\mathrm{S}-\mathrm{P}$ & P-S / S-P-O-K-K \\
\hline 12 & & P-S / S-P-P \\
\hline 13 & & P-S-K / S-P-K \\
\hline 14 & & P-S / S-P-Pel / P-S \\
\hline 15 & & P-P-P-S-K \\
\hline 16 & & P-O-S-P \\
\hline 17 & & P-K-S-P-K \\
\hline
\end{tabular}

Putrayasa, I. B. (2019). Syntactical analysis of essays. International Journal of Social Sciences and Humanities, 3(2), 156-164. https://doi.org/10.29332/ijssh.v3n2.307 


\begin{tabular}{|l|l|l|}
\hline 18 & & P-K-S-P-K / S-P \\
\hline 19 & & P-S / S-P / P-S / P-S-Pel \\
\hline 20 & & K-S-P-P \\
\hline 21 & & K-S-S-P-K \\
\hline 22 & & K-S-P-O / K-S-P-P-K \\
\hline
\end{tabular}

The table above shows that the sentence structure contained in essays of class VI elementary school students in Buleleng regency, Bali province is quite varied, both those found in single sentences and compound sentences. The variability of this structure is reflected in the sentences used to express ideas through his essay. The variability of the sentence structure is used to avoid the monotony and make the ideas conveyed effectively. The variability of the sentence structure used by these students shows that the level of intellectual maturity and level of language ability is quite high. This is in accordance with the views of Winch et al., (2006), who said that the higher the level of one's intellectual maturity, the higher the level of language ability. This means that the high level of a person's language skills will also influence the high variety of sentences used in conveying ideas.

\section{Conclusion}

Based on the explanation above, it can be concluded as follows: (1) the types of sentences contained in essays of class VI elementary school students in Buleleng regency, Bali province can be divided based on (a) contents, there are 219 declarative sentences; (b) the number of clauses, there are 74 sentences per day, 145 compound sentences; (c) the predicate of its formers, there are 216 verbal sentences and 3 nominal sentences; and (d) the nature of the actor's relationships, there are 201 active sentences and 18 passive sentences. (2) the unity of the sentence indicated by the existence of (a) Subject (S) and Predicate (P): 214 sentences categorized as clear unity of ideas; (b) 1 sentence is not clear the unity of the idea. The sentence whose unity of ideas is unclear is caused by the absence of S and P, only in the form of information; (c) without S, only contains P: 1 sentence, and (d) without P, only contains S: 3 sentences. (3) The structure of sentences, both single and multiple found in essays of class VI elementary school students in Buleleng regency, Bali province is quite varied. Based on the results obtained, it is recommended that students always pay attention to the type, unity, and structure of sentences in writing essays for the effectiveness of the ideas presented.

\section{Acknowledgments}

The author would like to acknowledge the editor and reviewer of IJSSH for their valuable time, support, and advice in completing the current research. 


\section{References}

Alwasilah, A. C. (2002). Pokoknya kualitatif: Dasar-dasar merancang dan melakukan penelitian kualitatif. Pustaka Jaya.

Batterink, L., \& Neville, H. J. (2013). The human brain processes syntax in the absence of conscious awareness. Journal of Neuroscience, 33(19), 8528-8533.

Bogdan, R. C., \& Biklen, S. K. (1990). Penelitian Kualitatif untuk Pendidikan. Jakarta: Pusat Antar Universitas.

Clifton. Jr, C. E., \& Frazier, L. (2010). Imperfect ellipsis: Antecedents beyond syntax?. Syntax, $13(4), 279-297$. https://doi.org/10.1111/j.1467-9612.2010.00142.x

Collins, C., \& Stabler, E. (2016). A formalization of minimalist syntax. Syntax, 19(1), $43-78$. https://doi.org/10.1111/synt.12117

Darlina, L. (2016). Relational grammar of passive in Japanese. International Journal of Linguistics, Literature and Culture, 2(2), 167-178.

Hatch, E. M. (1983). Psycholinguistics: A second language perspective. Newbury House Publishers, Inc., Rowley, MA 01969.

Huddleston, R. D., \& Uren, O. (1981). Declarative, Interogative, and Imperative in French dalam MAK Halliday dan JR Martin. Readings in Sytemic Linguistics: 231, 256.

Lincoln, Y. S., \& Guba, E. G. (1985). Naturalistic inquiry. Newberry Park.

Lindlof, T. R., \& Taylor, B. C. (2017). Qualitative communication research methods. Sage publications.

Nordquist, R. (2018). English as a foreign language (EFL). Grammar \& Composition.

Osborne, T., Putnam, M., \& Groß, T. (2012). Catenae: Introducing a novel unit of syntactic analysis. Syntax, 15(4), 354-396. https://doi.org/10.1111/j.1467-9612.2012.00172.x

Paridi, K., \& Sudika, I. N. (2018). Pronouns traces of grammar transformation version of government and binding. International Journal of Social Sciences and Humanities, 2(2), 175-186. https://doi.org/10.29332/ijssh.v2n2.162

Putrayasa, I. B. (2010). Penerapan Model Konstruktivisme Berpendekatan Inkuiri dalam Pembelajaran Bahasa Indonesia. Jurnal Pendidikan dan Pengajaran, 43(1).

Putrayasa, I. B. (2011). Studi Penelusuran Miskonsepsi dalam Pembelajaran Sintaksis (Tata Kalimat) dengan Model Konstruktivisme Berpendekatan Inkuiri pada Siswa Kelas I SMPN di Kota Singaraja, Kabupaten Buleleng, Provinsi Bali. Prosiding Konferensi Internasional Masyarakat Linguistik Indonesia-KIMLI.

Putrayasa, I. B. (2013). Penelusuran Miskonsepsi Dalam Pembelajaran Tata Kalimat Dengan Pendekatan Konstruktivisme Berbasis Inkuiri Pada Siswa Kelas I Smp Laboratorium Undiksha Singaraja. JPI (Jurnal Pendidikan Indonesia), 2(2).

Putrayasa, I. B. (2014). Kalimat Efektif (Diksi, Struktur, dan Logika) Edisi Revisi. Bandung: Refika Aditama.

Putrayasa, I. B. (2014). Pragmatik. Yogyakarta: Graha Ilmu.

Putrayasa, I. B. (2015, September). Pembelajaran bahasa Indonesia (kalimat: unsur objek dan adverbial) dengan model konstruktivisme berpendekatan inkuiri. In Prosiding Seminar Internasional, Malang (pp. 2829).

Putrayasa, I. B. (2016). Kajian Pengajaran Bahasa dan Sastra Indonesia. In Makalah Disampaikan dalam Seminar Nasional Bahasa, Sastra, dan Pengajarannya IV. Denpasar.

Putrayasa, I. B. (2017). Unity and effectiveness of the abstract language beginner lecturer research institution (Undiksha) 2015. IOSR Journal of Humanities and Social Science (IOSR-JHSS). V0I, 22, 23-28.

Putrayasa, I. B. (2017). Unity and effectiveness of the abstract language beginner lecturer research institution (Undiksha) 2015. IOSR Journal of Humanities and Social Science (IOSR-JHSS). V0l, 22, 23-28.

Putrayasa, I. B. (2018, September). Kemampuan Menguasai Aspek Kalimat Teks Bahasa Indonesia pada Siswa Kelas VII SMP Laboratorium Undiksha. In Seminar Nasional Bahasa, Sastra, dan Pengajarannya (Vol. 5, pp. 52-57).

Putrayasa, I. B., \& Seni, I. K. I. P. (2003). KurikulumBerbasisKompetensi (KBK): Rancangan dalamPengimplementasiannya. JurnalPendidikandanPengajaran IKIP NegeriSingarajaEdisi Khusus (XXXVI), 110-120.

Putrayasa, I. B., \& Susana, A. (2007). Analisis Kalimat (fungsi, kategori, dan peran). Refika Aditama.

Putrayasa, I. B., Ramendra, D. P., \& Aryana, I. B. P. M. (2018, August). The Types of Sentence in the Essays of Grade VI Elementary School Students in Bali Province: A Syntactic Study. In Fourth Prasasti International Seminar on Linguistics (Prasasti 2018). Atlantis Press.

Putrayasa, I. B. (2019). Syntactical analysis of essays. International Journal of Social Sciences and Humanities, 3(2), 156-164. https://doi.org/10.29332/ijssh.v3n2.307 
Putrayasa, I. B., Ramendra, D. P., \& Aryana, I. B. P. M. (2018, August). The Types of Sentence in the Essays of Grade VI Elementary School Students in Bali Province: A Syntactic Study. In Fourth Prasasti International Seminar on Linguistics (Prasasti 2018). Atlantis Press.

Putrayasa, I. B., Ramendra, D. P., \& Aryana, I. B. P. M. An Analysis of Sentences' Unity of Students' Compositions at Grade VI of Elementary Schools in Bali Province.

Putrayasa, I. B., Ramendra, D. P., \& Aryana, P. M. (2018, December). The Analysis of Sentences Structure of Students Compositions at Grade VI of Elementary Schools in Bali Province. In International Conference on Language, Literature, and Education (ICLLE 2018). Atlantis Press.

Reyner, K., Heffner, A. C., \& Karvetski, C. H. (2016). Urinary obstruction is an important complicating factor in patients with septic shock due to urinary infection. The American journal of emergency medicine, 34(4), 694-696. https://doi.org/10.1016/j.ajem.2015.12.068

Robert-Burton, N. (1997). Analysing sentences.

Syarifaturrahman, W. K., Hanafi, N., \& Nuriadi, -. (2017). The inflection of Sasak language in Kuripan village. International Journal of Social Sciences and Humanities, 1(3), 155-181. https://doi.org/10.29332/ijssh.v1n3.69

Tai, H. Y. (2015). Writing development in syntactic complexity, accuracy and fluency in a content and language integrated learning class. International Journal of Language and Linguistics, 2(3), 149-156.

Winch, G. (Ed.). (2006). Literacy: Reading, writing and children's literature. Oxford University Press, USA.

Yani, L., Artawa, K., Satyawati, N. M. S., \& Udayana, I. N. (2018). Transitivity construction of verbal clause in Ciacia language. International Journal of Linguistics, Literature and Culture, 4(3), 15-23.

\section{Biography of Author}

\begin{tabular}{|c|c|}
\hline & \\
\hline & $\begin{array}{l}\text { Ida Bagus Putrayasa is a professor at the Ganesha University of Education, Bali- } \\
\text { Indonesia. He was born in Desa Banjar, Buleleng Regency on February } 10^{\text {th }} \text {, } \\
\text { 1960. He graduated his primary school in Desa Banjar (1972), a junior high school } \\
\text { in Desa Banjar (1975), SPG in Singaraja (1979), S-1 in Singaraja (1984 ), S-2 in } \\
\text { Bandung Teachers' Training College (1998), and S-3 at UPI Bandung (2001). He } \\
\text { was in } 2004 \text { established as a professor in the linguistics field. He lived at Jalan } \\
\text { Laksamana Barat, Gang Sandat No.7, Desa Pemaron, Singaraja-Bali. Ph. } \\
\text { 081338570420. Email: ibputra@gmail.com }\end{array}$ \\
\hline
\end{tabular}

